ISBN 978-81-933894-6-1

2017 4th International Conference on Business, Education, Law and Interdisciplinary Studies

(BELIS-17)

London (UK) June 29-30, 2017

\title{
Analysis of E-commerce Website--VANCL
}

\author{
Taozhi Si *, Wenrong Jiang and Xaoming $\mathrm{Hu}$ \\ Shanghai Polytechnic University \\ Email: tzsi@sspu.edu.cn
}

\begin{abstract}
This article presents the history of VANCL, the analogy of domestic and foreign similar site analysis, VANCL SWOT analysis, improvement measures and the final evaluation and improvement of divergence points. This paper also analyzes the VANCL unique business model as well as its profit model from the perspective of a variety of finished products about VANCL.VANCL has been able to stand out in the e-commerce market, and not just rely on his powerful marketing model and corporate culture, it also bears some weight in its development process. "Integrity" and "pragmatic" and "innovation" are VANCL three corporate cultures. Currently, VANCL profit model is to charge a 5\% commission from sales of third-party brands, although this business is still not making a lot of profits, but now VANCL is making a platform development which not only can cover different needs of existing customers and also can bring new customers.
\end{abstract}

Keywords: VANCL; development model; current situation; existed problems; future development.

\section{Introduction}

\subsection{Background}

VANCL, former founder Mr. Chen Nian founded Joyo, Joyo main backbone of the operation of both the original staff. VANCL Since its establishment, the rapid development of operational efficiency, brand influence daily rise in Chinese clothing e-commerce [1-3]. According to iResearch data show that institutional 2009Q1, VANCL occupies 3.82\% of total B2C market share, ranked Jingdong, Amazon, after Dangdang, ranked fourth. VANCL adhere to brand quality international line, has now expanded its business to cover men's, women's, men's, women's, children's clothing, home, bags and cosmetics. VANCL clothing brand rooted in the Internet, using the online direct sales model to a place in the B2C field [4-6].

\subsection{Purpose}

Today's e-commerce market, shopping websites minority, "hegemony " Taobao naturally has its successful operation of the road, but the rest of the customer base of some relatively weak shopping websites are mostly just imitate each other, there is no post of their own operations mode, nothing new at all, and the pages are filled with a lot of advertising, giving a sense of insecurity.

VANCL has been able to stand out in the e-commerce market, and not just rely on his powerful marketing model and corporate culture, and he also bears some weight in its development process. "Integrity" and" pragmatic" and " innovation" is VANCL three corporate cultures. Any time, VANCL have the courage to face the problem on their own business, no secret, calm face; confront corporate interests, each VANCL employee personal gains, all to the interests of the team headed; in the development of roads, VANCL always uphold innovative spirit, the only constant innovation, absorb changes in order to change the status quo in order to gradually move toward success.

So, I chose VANCL --- started from selling a shirt to cover all kinds of clothing, bags, shoes and cosmetics are now shopping sites, analyze their business model and profit model. 


\subsection{Research}

This article is from the perspective of these new operating models VANCL shopping websites, as well as its profit model to analyze and discuss.

\section{Background in China and abroad}

\subsection{Domestic Research on shopping websites}

At present, there are more well-known domestic and a few on shopping websites, such as Jingdong Mall, Suning Tesco, Taobao, eBay, pat network, Dangdang and so on. Nevertheless, these shopping sites, in addition to giant Taobao, the rest of the shopping websites [7-8] are not enough unique features, there is no unique business model.

Suning Tesco , for example, although Tesco Suning Suning traditional business leader in the online mall, which itself has a strong logistics and integrated supply chain system, but its development in the field of electronic commerce is unsatisfactory, the reason is that he did not unique electrical supplier of business management. Similar VANCL, Suning Tesco started with appliances, the business gradually expanded to people's lives, bit by bit, however, Suning Tesco only will their business completely biased in favor ofelectrical appliances, do not care about the quality of service the rest of the product [9-10].

In addition, there is a very important point ----- web design, as online shopping, gives the first impression is the website design and page style and fluency. Suning Tesco website design is not enough beautiful, far from the first impression on other sites, and the entire page display is not smooth, greatly affect mood of users to browse the site.

\subsection{Abroad Research on Shopping Websites}

Compared with the shopping websites from domestic and foreign shopping websites, the last one is better to do. The typical examples are Saks Fifth Avenue, its website design is very reasonable, and it dominated throughout the pages of pictures, giving a feeling of not cumbersome, and the vertical columns of different areas of their split, it navigation well-designed embedded web style, the use of technology will be a lot of content hidden layers are completely hidden, so that the page looks simple and elegant. In addition, he's shopping page is not simply jump a new page, but on the original page, use a pop-up page JS technology, customers can simply make a purchase, to the shopping process greatly improves the efficiency of the overall site style though cannot say great design sense, but also makes a refreshing feeling in the details of the deal is also in place.

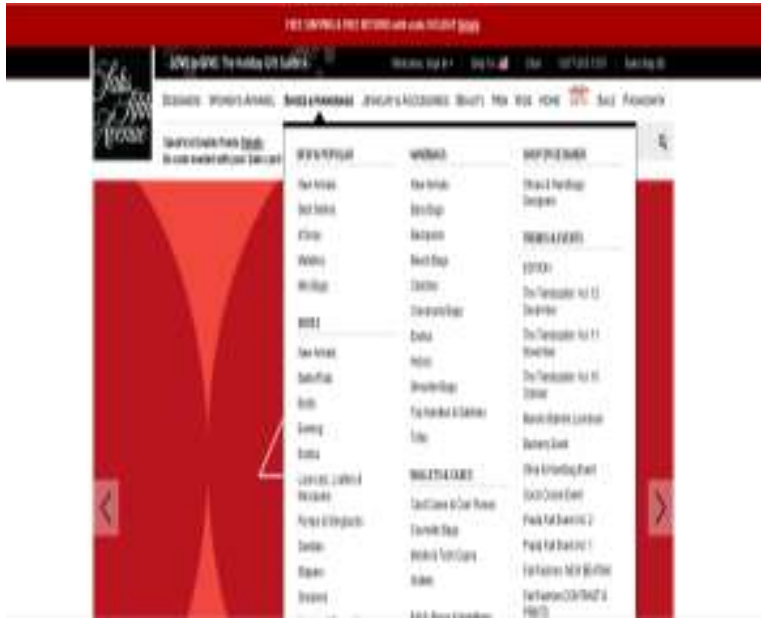

Fig. 1: Saks Fifth Avenue index of website

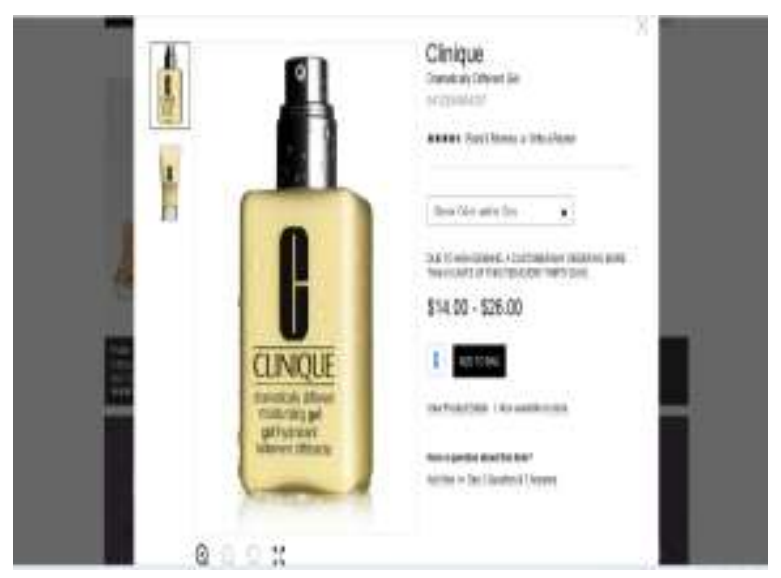

Fig. 2: Saks Fifth Avenue shopping page 


\section{SWOT Analysis}

\subsection{VANCL SWOT Analysis}

\subsubsection{Strength}

1) low-cost advantage ----- traveling light

VANCL using direct B2C model, relying solely on the majority of brand awareness, viral marketing relies grab customers by improving supply chain system are upstream and downstream resources. Because VANCL no factories, workers, there is no physical store sales, so the price positioning in the PFP levels, making the brand monopoly in the upstream leader.

2) Brand positioning advantage ---- all are guests

VANCL brand meaning mortals are off VANCL is an honest brand. It advocated a simple lifestyle, and removed the pompous vanity, most comfortable, most decent life philosophy of life.

3) Team resources ---- network giant hand in hand, to join the top designers

VANCL founder and staff, are the backbone of the former Joyo level figures, has extensive business experience and practical philosophy. In addition, VANCL products are led by noted designers worldwide planning to make VANCL grade refined products.

4) Organizational system is perfect ----- powerful marketing planning department

Currently in Sina, Tencent, Netease and other major sites can be seen VANCL advertising, VANCL viral marketing will be a good idea into actual operation, the use of Internet advertising, SEO, search engine advertising, email marketing, blog topic of marketing, word of mouth marketing, publicity, etc., and more importantly, VANCL advertising beautifully designed, targeted content, a good grasp of the user's eye and reputation, their products and brand popularity.

\subsubsection{Weakness}

1) No core competencies

An e-commerce enterprise in order to win the war must have its own unique, dedicated core value system, and form its own core competitiveness. VANCL in terms of technology, products, brands, distribution are dependent on third parties, unable to form their own core competitiveness.

2) Control of upstream suppliers is not strong, the speed of product quality and supply insecurity

VANCL products are dependent on third parties, the use of network marketing model, without their own production lines and brand concept, not their direct sales channels entities, their products right outsourcing to other companies, which may result in slower service reduce customer loyalty.

3) Lack of proper customer service and after-sales service system

VANCL as online trading site, although it guarantees 30 days unconditional return and compensation of return shipping customer, its customer service and customer satisfaction is not completely, the reaction speed is too slow, complicated process to find customer service, customer service position so obvious place it is important to note that VANCL. Another service system is not perfect, I could not find return customer, etc., which will reduce the buying enthusiasm and brand loyalty of customers, we all know, online shopping, user reputation plays a decisive factor.

\subsubsection{Opportunity}

With the rapid development of e-commerce, online shopping has become a new way to shop. In 2009 reached 267 billion yuan net purchase, up 90.7\% compared with 2008, the number reached 130 million online shopping. In addition, VANCL price close to the people, to meet the needs of users, while more expensive than the price of the same industry, so, VANCL markets not only throughout the CBD, but also throughout all offices and work areas of major cities.

\subsubsection{Threats}

Direct network access threshold feet, as long as there is sufficient supply channels, to get production, the manufacturer's lowest price product, there is a rich source of supply, and then build a basic platform can be opened. Currently, many well-known brands such as the line "Metersbonwe", "Semir" and so are starting a 
virtual business, and various well-known sites such as "Dangdang" and so began operating its own branded products, competition is fierce.

\subsection{Total Analysis}

VANCL founder of the aged in the innovation business model to imitate PPG eventually built VANCL. With e-commerce deep understanding of Internet marketing, VANCL constantly micro innovative ways to improve customer experience. Where the customer in recent years, using a variety of network marketing innovative models to enhance their brand awareness, such as Internet advertising, SEO, search engine advertising, word of mouth marketing, etc. These marketing tools adapt for the development of e-commerce era, the brand is deeply VANCL people. At the same time, VANCL has been advocating low-cost marketing strategies to make high-end fashion and exquisite design completely infiltrated the average consumer lives. And has been working on the site background VANCL shopping process optimization and page design techniques, in recent years, VANCL invested ten million yuan language technology research and development, VANCL convinced that in order to build the capacity of an R \& D cannot be surpassed and replication, in addition, VANCL guarantee 30 days unconditional return and take consumers return shipping, this move is rare in ecommerce.

However, as his own brand of electric providers website, VANCL ineffective integration with third-party logistics, distribution services inadequate, poor integration with upstream suppliers, their products have problems, these factors are likely to influence the minds of consumers in their VANCL image VANCL are facing a dilemma currently developing. In addition, a very important point in the development process is VANCL not ignore the many unofficial sites for post negative comments. The rapid development of the enterprise will be a variety of problems and obstacles, if mishandled or treatment is not timely, it will give consumers a bad impression, and evolved into a network crisis, and thus will affect word of mouth marketing, the prospects for VANCL would not be optimistic.

\section{Evaluation and Improvement}

Judging from the few chapters before, VANCL has its unique business model, but there are many areas for improvement. Here, we evaluate and analyze the experience of VANCL business model and the need for improvement.

\subsection{VANCL Profit Model}

\subsubsection{Network of Direct Sales Model}

VANCL a network and catalog sales approach, when consumers visit the website, merchandise information at a glance, exquisite web design and user-friendly layout layout, simplifying the consumer's purchase process. While eliminating the need for physical stores and auto-related expenses, reduce costs, ensure that the price advantage.

\subsubsection{Asset-Light Model}

From the point of view VANCL, VANCL a fabless, two non-production equipment, only the market, design department, call centers and warehouses. VANCL according to the customer or potential future market demand, the development of a variety of products, and then the next call center or customer orders through a network, and finally through the logistics company to deliver products to the customer

\subsubsection{Marketing Channels}

VANCL viral marketing will be a good idea into actual operation, the use of Internet advertising, SEO, email marketing, blog topic of marketing, word of mouth marketing, publicity, etc., and more importantly, VANCL advertising beautifully designed, content targeted, well captures the user's eye and reputation, their products and brand popularity. 


\subsection{Problems in Profit Model}

\subsubsection{VANCL Profit Model}

In terms of quality assurance, VANCL low-cost strategy has been implemented, which rapidly expanded its market share, dominate the market is extremely important, but with the accumulation of time, problems began to emerge, once the online newspaper of the product quality VANCL question, netizens have complained Eslite 29 yuan T inferior, where customers caught in "refunds door." So, I think any one brand, has its core values. Reflect the value of any product, be based on quality, where the customer wants to go farther and more stable, we must confront the root causes of their problems and make the necessary guarantees of their quality.

\subsubsection{VANCL Marketing Cost Problems}

VANCL invest heavily in online advertising, the use of various channels to expand its brand awareness, however, VANCL Youyi cheap product strategy to attract customers, in addition, VANCL choose a third-party logistics, shipping and handling fee on behalf of receivables, packaging materials and related accessories, taxes, and so are a lot of expenses, this means big VANCL's hard to imagine the cost of marketing. Shirt from the Internet direct marketing point of view, to some extent, can indeed save a lot of channel costs, while VANCL, the high cost of marketing channels to fully offset the cost advantage, this problem will affect future VANCL sustainable development.

\section{Summary}

According to the analysis and multi-angle analysis above, this paper VANCL from the history of domestic websites similar analogy analysis, SWOT analysis, improvement measures and the final evaluation and improvement of divergence points to write. Current, VANCL profit model is to charge a 5\% commission from sales of third-party brands, although this business is still not making a lot of profits, but, VANCL now to platform development, existing customers can not only cover different consumer needs, you can also bring new customers to their own needs.

According to 2013 market share of the electricity supplier survey, where the customer's market share was $1.2 \%$, in the days of cat, Jingdong, Suning Tesco, Amazon China and Dangdang, the United States, then the only product ranked 10th. However, VANCL is the only top ten independent brand electric providers, other nine are platform-type or channel-based electricity supplier. Therefore, I believe, VANCL in its future development, consolidating their advantage in getting to the platform type or channel-type development, its future will be bright.

\subsection{Future Prospects for VANCL}

VANCL innovation in the market, electricity providers, electricity suppliers in 2013 survey, VANCL still ranked in commercial enterprises in the top ten. VANCL major center put their products in terms of clothing, so I suggested, VANCL can conduct a comprehensive model strategy. VANCL no shortage of fame, and portals can do some cross advertising, increase brand effectiveness, make profits diversified maximized. In addition, VANCL can develop their own logistics, maximizing enhance consumer shopping experience.

Although VANCL is an independent brand business enterprise, profit efficiency below the "Lynx" platformbased electricity providers such large enterprises. But, I think, VANCL is a subversion of our predecessors will follow, owners of advanced management concepts, it makes the brand more valuable than the platform. Therefore, I suggest, VANCL to treat life the same view of their business, in this perspective implies humility, if not humble operators are likely to overstate the power of the so-called business model. So, VANCL not coming winter, but spring has begun.

\section{Acknowledgment}

This work is supported by the Key Disciplines of Computer Science and Technology of Shanghai Polytechnic University (No. XXKZD1604) and the Application Oriented Undergraduate Professional Construction Project of Shanghai (No. A30DB172202-4). 


\section{References}

[1] Wenrong Jiang, Yingyan Liu. Analysis of the double 11 ouyeel business promotion effectiveness[C]. 2016 ISSGBM International Conference on Information, Communication and Social Sciences (ISSGBM-ICS 2016), Dubai, United Arab Emirates, Singapore Management and Sports Science Institute, October 8, 2016, 49-55.

[2] Wenrong Jiang. Analysis of the E-commerce website-Lianliangou[C]. 2016 2nd International Conference on Electronics, Network and Computer Engineering(ICENCE2016), Yinchuan, China, Advances in Computer Science Research, Vol67. Auguest 13, 2016, 674-679.

[3] Wenrong Jiang, Shiwei Li. Analysis of Xiaomi Tech's E-commerce model[J]. 2nd International conference on Ecommerce and Contemporary Economic Development (ECED 2015), Nanjing, China, December 5-6, 2015, DEStech Publications, Inc. 196-200.

[4] Wenrong Jiang, Jian Chen.Analysis of the wabsite-Hj operations[J]. 2015 3nd International Conference on Applied Social Science Research (ICASSR 2015), Limassol, Cyprus, October 4-5, 2015, 103-106.

[5] Wenrong Jiang, Jian Chen.Traditional Enterprises Transformation and Strategy to Deal with E-Commerce[J]. 2015 4th International Conference on Physical Education and Society Management (ICPESM 2015), Singapore, December 6-7, 2015, Lecture Notes in Management Science, 2015(12), Vol 47, 301-306.

[6] Wenrong Jiang, Min Liu. Analysis and Exploration Undergraduate Students E-Commerce Business Model[J]. 2014 International Conference on Business, Economics and Management (BEM 2014), Hongkong, China, 2014(3):3-8. 